Artykuły

Studia luridica Lublinensia vol. XXV, 3, 2016

DOI: $10.17951 /$ sil.2016.25.3.53

\title{
Waldemar Bednaruk
}

Katolicki Uniwersytet Lubelski Jana Pawła II

wbednaruk@kul.lublin.pl

\section{"Ambitia podczas y pycha częściey się uczyć każą, niż cnota...", czyli o szkodliwości pobierania nauk według Stanisława Lubomirskiego*}

\author{
"Ambition and Pride Bid to Learn More than Virtue..." - \\ about the Dangers of Learning According to Stanisław Lubomirski
}

\section{STRESZCZENIE}

W czasach upadku szkolnictwa Stanisław H. Lubomirski głosił wyższość przyrodzonego rozumu i rozsądku nad wiedzą akademicką. Ten powszechnie znany i szanowany magnat - filozof, zwany był przez współczesnych ,polskim Salomonem”. Jego poglądy, w których widać wyraźny ślad fascynacji stoikami, cieszyły się ogromną popularnością co najmniej do połowy XVIII w.

Słowa kluczowe: szkolnictwo polskie w XVII w.; Stanisław H. Lubomirski; cnota; stoicy

„Ambitia podczas y pycha częściey się uczyć każą, niż cnota, y nie ieden lenistwo y niedbalstwo, które iest cnoty trucizna, naukami y tytułem cnoty przyodział" - tak brzmi pełne zdanie z dzieła Stanisława Herakliusza Lubomirskiego Rozmowy Artaksesa i Ewandra1, wydanego po raz pierwszy w 1683 r., a później wielokrotnie wznawianego ${ }^{2}$.

Wspomniana trzykrotnie w tym jednym zdaniu cnota jest dla siedemnastowiecznego autora celem, do którego powinien dążyć każdy prawy człowiek.

* Tezy tego artykułu były prezentowane przez autora podczas XXV Ogólnopolskiego Zjazdu Historyków Prawa w 2014 r. w Krakowie, jednak nie zostały dotychczas opublikowane.

${ }^{1}$ S.H. Lubomirski, Rozmowy Artaksesa i Ewandra, w których polityczne, moralne i naturalne uwagi, zawarte wedle podanych okazyj, tak jako mówione właśnie byly prawdziwie wyrażone sa spisane, Warszawa 2006, s. 26.

${ }^{2}$ W latach 1694, 1708, 1734 i 1745. Tak: C. Hernas, Barok, Warszawa 1976, s. 484. 
Czymże więc jest ta cnota? W filozofii jawi się nam jako naczelne pojęcie etyczne, do którego wyjaśnienia dążą kolejne pokolenia mędrców. Samo słowo cnota (z łac. virtus, z gr. areté) kojarzy się przy dosłownym tłumaczeniu z męstwem, odwagą, bohaterstwem (słowo pochodzi od vir, viri - 'mąż', 'mężczyzna'). Początkowo, szczególnie w okresie archaicznym, gdy nauka dopiero kształtowała się w świecie pełnym przemocy i wojen, cnotą było męstwo okazywane w obliczu zagrożenia życia, a więc przede wszystkim w boju. Dopiero później cnota stała się zaletą moralną oderwaną od dokonań na arenie wojennej, zdatnością (zdolnością) do czynienia dobra przez wzorcowe (idealne) wypełnianie należnej nam w życiu roli ${ }^{3}$.

W starożytnej Grecji, w czasach Homera, cnotę rozumiano jako odwagę (dzielność), przyznając moc jej posiadania jedynie osobom możnym, w myśl zasady: „Komu się dobrze wiedzie, ten jest dobry, a komu źle, ten jest zły”. Ten swoisty elitaryzm cnoty, stanowczo odrzucony przez sofistów, wykluczał możliwość jej osiągnięcia przez przedstawicieli nizin społecznych ${ }^{4}$.

Z czasem jednak, pod wpływem sofistów, a później też Sokratesa i jego następców, nastąpiła radykalna zmiana w pojmowaniu cnoty, która coraz ściślej była wiązana ze społeczną rolą danej jednostki w strukturze państwa. Inne więc było rozumienie cnoty w stosunku do arystokracji, dla której mądrość i odwaga na scenie politycznej, ale i na wojnie, roztropność w radzie i przy podejmowaniu decyzji politycznych były wyrazem tej właściwości. Inna cnota natomiast powinna cechować kupca, a jeszcze inna - pasterza czy niewolnika ${ }^{5}$.

W okresie klasycznym jako cnotę rozumiano zatem pewną praktyczną zdolność do osiągania stawianych celów, czyli skuteczność w działaniu - tak ją pojmowali sofiści, z którymi nie zgadzał się Sokrates, odrzucający relatywizm etyki sofistów, a potem kontynuatorzy jego nauk: Platon i Arystoteles. Szczególne zasługi w definiowaniu cnoty położył Platon, tworząc kanon czterech cnót antycznych, które później przyjęło też chrześcijaństwo i nazwało kardynalnymi, a były to: roztropność, sprawiedliwość, umiarkowanie i męstwo. Jeszcze dalej poszedł Arystoteles, który uznał, że celem działania człowieka jest doskonałość jednostki osiągana we właściwym (rozumnym) postępowaniu, prowadzącym do cnoty ${ }^{6}$.

Nie mniej ważne dla rozumienia poglądów Lubomirskiego były twierdzenia stoików, które wydają się najbliższe jego duszy. Otóż dążyli oni do osiągnięcia stanu cnoty, którą pojmowali jako całkowite zaakceptowanie praw natury, ich zrozumienie i życie z nimi w pełnym stanie harmonii. Cnota według nich to pewien

${ }^{3}$ Arystoteles, O cnotach i wadach, [w:] Dzieła wszystkie, przeł. D. Gromska, L. Regner, W. Wróblewski, t. 5, Warszawa 1996, s. 496.

${ }^{4}$ Ibidem.

5 Ibidem, s. 498 i n. Zob. też: Filon Aleksandryjski, Pisma, oprac. L. Joachimowicz, t. 1, Warszawa 1986, s. 233 i n.

${ }^{6}$ Por. W. Tatarkiewicz, Trzy etyki: studium z Arystotelesa, [w:] Droga do filozofii, red. W. Tatarkiewicz, t. 1, Warszawa 1971, s. 324 i n. 
naturalny stan ducha, możliwy do osiągnięcia po odrzuceniu „złych popędów”. Cnota to dobro i szczęście. Człowiek cnotliwy musi być jednocześnie dobry, zaś jego szczęściu nie mogą przeszkodzić czynniki zewnętrzne, które dla prawdziwego mędrca powinny być nieistotne ${ }^{7}$. Od tamtej pory, mówiąc o cnocie, obracano się wokół starożytnych pojęć, nie wnosząc istotnych zmian, choć oczywiście szczególnie chrześcijanie interesowali się tą kwestią i poczynili pewne ustalenia, które jednak nie znajdują głębszego odbicia w twórczości autora Rozmów.

A jak rozumiał cnotę sam Lubomirski? Nie dowiemy się tego wprost z rozmowy Artaksesa z Ewandrem. Raczej wytyka on tutaj błędy w rozumieniu tego pojęcia. Krytykuje obłudę i fałsz współczesnego świata, sugerując przez to, by strzec się takich postaw. Bliższych wskazówek należy szukać w całej jego twórczości ${ }^{9}$ i w całym jego życiu. Niejednokrotnie z kontekstu wynika, że nieobce mu było archaiczne rozumienie tego pojęcia, gdzie odwołuje się do cnót przystających danemu stanowi, a więc stanom niższym, takim jak pracowitość, pobożność i posłuszeństwo, wyższym zaś odwaga, mądrość, sprawiedliwość i umiarkowanie. Był on bowiem przeciwnikiem mieszania się stanów, czemu dał niejednokrotnie wyraz w swojej twórczości, oraz ich ról w społeczeństwie. Istniejącą strukturę społeczną uważał za dobrą, miłą Bogu i nie widział najmniejszego powodu, by ją zmieniać, szczególnie że mieścił się na jej szczycie ${ }^{10}$.

Kim więc był Stanisław Herakliusz Lubomirski? Był on synem słynnego rokoszanina, księcia Jerzego Sebastiana Lubomirskiego, marszałka wielkiego koronnego i hetmana polnego koronnego, od którego nazwiska wziął swą nazwę bunt przeciw królowi Janowi Kazimierzowi, trwający w latach 1665-1666. Urodzony w 1642 r. autor Rozmów również doszedł do wysokich urzędów, piastując kolejno funkcje podstolego koronnego, marszałka nadwornego koronnego i wreszcie marszałka wielkiego koronnego ${ }^{11}$. Wpływowy dzięki swojej inteligencji, zamożności, koligacjom i piastowanym urzędom, nie mniej niż jego ojciec,

${ }^{7}$ G. Reale, Historia filozofii starożytnej, przeł. E. Zieliński, t. 3, Lublin 1999, s. 332 i n.

${ }^{8}$ Zob. Katechizm Kościoła Katolickiego, cz. 3, Pallotinum 1994, art. 7: Cnoty, nr 1804, „Cnoty ludzkie są trwałymi postawami, stałymi dyspozycjami, habitualnymi (trwale zdolnymi) przymiotami umysłu i woli, które regulują nasze czyny, porządkują nasze uczucia i kierują naszym postępowaniem zgodnie z rozumem i wiarą. Zapewniają one łatwość, pewność i radość w prowadzeniu życia moralnie dobrego. Człowiek cnotliwy to ten, który dobrowolnie czyni dobro. Cnoty moralne zdobywa się wysiłkami człowieka".

9 Przykładem mogą być rozważania autora o godnym i cnotliwym postępowaniu młodego człowieka, jakie zawarł w instrukcji dla swoich synów. Por. S.H. Lubomirski, Instrukcyja synom moim [do] cudzych krajów ode mnie wyprawionym, Teodorowi i Franciszkowi Lubomirskim, w Jazdowie, D. 29 Novembris A. 1699, [w:] Wybór pism, oprac. R. Pollak, Wrocław 1953, s. 273 i n.

${ }^{10}$ Analizę wczesnej twórczości Lubomirskiego, a w szczególności jego moralizujących utworów dramatycznych, zob. C. Hernas, op. cit., s. 474.

${ }^{11} \mathrm{~W}$ międzyczasie posła na sejm i marszałka sejmu. Zob. Polski Słownik Biograficzny, red. E. Rostworowski, t. 18, Wrocław 1973, s. 47 i n.; J. Dąbkowska-Kujko, Wprowadzenie do lektury, [w:] S.H. Lubomirski, Rozmowy..., s. 6 i n. 
odgrywał dużą rolę w ówczesnym życiu publicznym. Prowadził samodzielną politykę dynastyczną, popierając jednych władców (np. Michała Korybuta Wiśniowieckiego) bądź sprzeciwiając się innym (np. Janowi III Sobieskiemu), a nawet myśląc poważnie o koronie dla siebie, po śmierci Sobieskiego ${ }^{12}$.

Dla nas ważniejsze wydają się jednak jego dokonania na polu literackim, choć niewątpliwie jedne mają tu ścisły związek z drugimi i widać, że przelewane na papier przemyślenia wynikają z własnych, nieraz trudnych czy wręcz bolesnych, doświadczeń autora. Był osobą gruntownie wykształconą, jak na tamte czasy, zaś jego edukacja odbywała się według najlepszych ówczesnych wzorców. Po ukończeniu krajowego kolegium pijarskiego 17-letni magnat wyruszył w trzyletnią podróż po Europie, by poznać świat, nabrać ogłady i zdobywać wiedzę. Najdłużej, bo aż 1,5 roku, przebywał we Francji, gdzie obcował z otoczeniem Ludwika XIV, poznawał molierowski teatr, a także poglądy jansenistów ${ }^{13}$. Potem wyruszył w podróż do Hiszpanii, gdzie odwiedził króla Filipa IV, w Rzymie został przyjęty przez papieża Aleksandra VII, zaś w Wiedniu - przez cesarza Leopolda I. Poznane podczas podróży wzorce włoskie w literaturze będą towarzyszyły jego twórczości przez całe życie ${ }^{14}$.

Widać to wyraźnie w jego wczesnych doświadczeniach $\mathrm{z}$ dramatem i poezją, a i późniejsze dzieła noszą ślady młodzieńczych fascynacji. Później jednak więcej czasu poświęcał moralistyce i publicystyce literackiej, nad którymi unosił się wyraźny duch stoika Seneki. Niewątpliwie zmiana ta miała ścisły związek z działalnością polityczną Lubomirskiego, zaś głoszone tą drogą poglądy pozwalały wywierać znaczny wpływ na szlachtę, budując obraz magnata-filozofa. Był to wizerunek dość trwały, o czym świadczą liczne wznowienia jego dzieł, nawet wiele lat po jego śmierci ${ }^{15}$.

Wracając do zacytowanych na początku słów, w których Lubomirski stwierdza, że to próżna ambicja, nie wskazując, czyja - rodziców czy samych uczących się - częściej popycha do wchodzenia na tę drogę życia niż cnota, stwierdzić trzeba, że on sam, będąc osobą gruntownie wykształconą, o wszechstronnym umyśle, błyszczącym na tle epoki, która przecież nie sprzyjała rozwojowi nauki, nie mógłby, będąc tym, kim był, traktować poważnie własnych twierdzeń. Jest więc to zdanie pewnego rodzaju prowokacją, chyba że zalicza on siebie do tych

${ }^{12}$ R. Pollak, Wstęp, [w:] S.H. Lubomirski, Wybór pism, oprac. R. Pollak, Wrocław 1953, s. XXVII in.

${ }^{13}$ W. Szczygieł, Źródła „Rozmów Artaksesa i Ewandra” S.H. Lubomirskiego, Kraków 1929, s. 53; C. Hernas, op. cit., s. 470.

${ }_{14}$ Tak: W. Roszkowska, Włoski rodowód komedii S.H. Lubomirskiego, Wrocław 1960, s. 27 i n.

${ }^{15}$ C. Hernas, op. cit., s. 476; Polski Stownik Biograficzny, s. 47 i n. 
naprawdę nielicznych, wręcz wyjątkowych, o których wspomina na początku, jako uczących się właśnie dla cnoty. Reszta zaś tylko udaje, że jej poszukuje, w rzeczywistości zaś chodzi im o próżną chwałę, dobre samopoczucie, zaspokojenie prywatnych ambicji i nakarmienie ego. Wtedy nauka staje się tylko farbą do pozłocenia i zakrywania własnych wad i złego charakteru. Lubomirski twierdzi wręcz, że więcej ludzi uczy się po to, by własne niedoskonałości wyćwiczoną obłudą i omamieniem, czyli pozornymi naukami, ozdobić, niż po to, aby nagą, prostą i szczerą cnotę naśladowaćl6. Po tych kilku ostrych stwierdzeniach daje liczne i dobrze uzasadnione przykłady na poparcie swojej tezy.

Taki gramatyk i lingwista - czy on myśli, aby mając takie umiejętności, prawdę głosić, czy raczej aby dużo w różnych językach rozprawiać i popisywać się swoimi umiejętnościami? Czyż za czasów Adama, kiedy tylko jeden język był, cnota nie kwitła? A potem, kiedy w wieży Babel pojawiły się różne języki, czy cnocie to pomogło? Bynajmniej - odpowiada.

A taki polityk? Praktykując w tym zawodzie, uczy się subtelności i ostrożności w postępowaniu z ludźmi, oducza zaś szczerości i poufałości. Swoją sztukę kieruje wówczas na szkodę i oszukanie bliźniego bardziej niż na pomoc i ozdobę państwa. Dlatego uważa, że wszystkie narody, które są mniej polityczne, a bardziej prostolinijne ${ }^{17}$, jak Tatarzy, skrupulatniej pilnują prawa i sprawiedliwości niż te, które się za uczone i mądre uznają, jak słynący z obłudy Grecy. „Tatarowie nie politycy, nie umieją sejmować ani wymownych perswazyj, a zgodzą się w minucie na jedno, a drudzy sejmują pół roka i ostrożnością uczenie i dowcipnie nadrabiają, a nigdy zgody i prawdziwej miłości między stanami królestwa być nie może. Cóż tedy ma nad prostotę uczona polityka w prawdziwej drodze do cnoty?" - pyta. „Nic bynajmniej” - odpowiada natychmiast ${ }^{18}$.

A teolog? W uprawianej przez niego nauce, mówiącej o Bogu i tak obszernie o Nim uczącej, możemy widzieć najlepszą drogę do cnoty, ale jakżebyśmy się ciężko pomylili! Teolog bowiem, mówiąc o Bogu, pysznieje, a prostak, nie mówiąc o Nim, bo nie śmie, na samą myśl staje się pokorny. Mojżesz był tylko pasterzem i nie znał teologii ani nawet imienia boskiego, a Bóg przychodził do niego i z nim rozmawiał. Szukał go sam i pokazywał mu się, pomagał mu i przez niego przemawiał do ludu wybranego. A my chcemy Boga poznać i opisać - zaszufladkować. Zgłębić jego zamysły i scharakteryzować boskie przymioty, tym samym próżno tylko tracimy czas, sprzeciwiając się cnocie wiary i pokory. Z poznawaniem Boga jest bowiem jak z lataniem Ikara: ,,...] im słońcu bliższy, tym jemu niebezpieczniejszy, bo woskowej kreaturze śmiertelne jest do słońca przymknienie"19.

${ }^{16}$ S.H. Lubomirski, Rozmowy..., s. 26.

17, ,...] co ich grubemi i prostemi zowiemy”. Zob. ibidem, s. 27.

${ }^{18}$ Ibidem.

19 Ibidem, s. 28. „Nie wspominam herezyj i bluźnierstw, które z zbytniej subtelności teologijnej fundament błędów swych wzięły”. 
Skoro nawet tak górnolotna nauka, traktująca o samym Bogu, nie prowadzi człowieka na drogę cnoty, to cóż można powiedzieć o innych? Tacy krasomówcy, oratorzy, kaznodziejami też zwani, potrafią tak wszystko obracać na obie strony, że rozeznać nie sposób, gdzie prawda w tej ich mowie się znajduje. A to przez to, że cały fundament tej sztuki tylko na mamieniu słuchacza jest osadzony. Usta powinny być przybytkiem nagiej prawdy, a są u nich źródłem fałszu i obłudy, które zdobią jedynie oratorskimi figurami. Człowiek cnotliwy według Lubomirskiego powinien posługiwać się mową, która po prostu, gruntownie słuszność, prawdę $\mathrm{i}$ istotną sprawiedliwość wyraża ${ }^{20}$.

Najgorszy jednak ze wszystkich jest według Lubomirskiego filozof! Jego próżność znana jest na całym świecie. A do tego leń to i próżniak, który na daremnych dysputach czas trawi, nigdy prawdziwej i istotnej natury rzeczy dojść, nie mogąc. Ufa pozorom, którymi się kontentuje, gardząc doświadczeniem. Dowody za nic ma, argumentów nie słucha, stąd byle prostak mądrzejszym jest od niego, gdyż stan rzeczy przyrodzonym sposobem poznać może z własnego doświadczenia, choćby obcując z przyrodą. Filozof raczej, w pogardzie mając fakty, woli gadać, niż pracować, i zamiast próbować samemu dojść prawdy, kontentuje się tym, co mu Platon, Arystoteles czy inny martwy filozof na papierze zostawił. Prostak zaś ustawicznie pracuje i nie próżną gadaniną, lecz doświadczeniem dowodzi praw natury i porządku rzeczy tego świata, bo przecież wszystko, co wiemy o tym świecie, nie z gadania pochodzi, tylko z obserwacji przyrody. Nawet bezrozumne zwierzęta są mądrzejsze od filozofów, gdyż więcej uczą nas o naturze niż filozofowie - twierdzi, podając przykłady mądrości zwierzęcejej

Prawnikom można powiedzieć, że im pan marszałek darował, gdyż o nich niewiele, a nawet zgoła nic prawie nie napisał, ale nie należy sądzić, by wynikało to $\mathrm{z}$ jego akcepatcji dla nich czy ich procederu. Raczej należy mniemać, iż nie miał on ich za ludzi parających się nauką, stąd i pisać wiele nie miał o czym. Zamieścił jednak wzmiankę i od razu zaznaczę, iż nie była ona nazbyt pochlebna, pisząc mianowicie o wyższości ludów prostych, czy wręcz prymitywnych, podając za przykład Tatarów, tak widział ich sądy: „Kiedy się sądzą, nie ufają w jurystów, ale w słuszność, bo subtelności nie znają ani się spodziewają fortelów i dowcipnych obron po sobie: kiedy zaś z sobą traktują, prędzej sobie uwierzą i dotrzymają, bo nie wiedzą, co to jest pretekst, co clausula, co salva, co garantia, ale z przyrodzenia dobrze wiedzą, co słowo, co obietnica, co szkoda, co pożytek, co cnota" 22 . Prawnicy byli więc w jego mniemaniu raczej rzemieślnikami niż uczonymi. Osobami, które za pieniądze wynajmują się do wyszukiwania luk w prawie i kruczków, by swój talent oratorski wykorzystywać do gmatwania sprawy i przeciągania postępowania.

${ }^{20}$ Ibidem, s. 28 i n.

${ }^{21}$ Ibidem, s. 29 i n.

${ }^{22}$ Ibidem, s. 27. 
„Prostotę Bóg chciał mieć za mądrość” - twierdzi Lubomirski, gdyż prosty rozsądek wystarczy człowiekowi, by podążał drogą cnoty. Widzi on bowiem jedną ścieżkę wiodącą do Boga - prostą i wygodną, natomiast nauki proponują rozumowi wiele dróg. Zupełnie niepotrzebnie sieją wątpliwość w umyśle, który jak pielgrzym w lesie gubi się, widząc wielość możliwości. A wszystko przez to, że niecnotliwi nauką się bawią, używają jej do tuszowania swoich grzechów i sprośności. Zamiast wrócić na właściwą drogę - drogę cnoty - i trzymać się jej, tłumaczą swoje złe czyny, tuszują je, bagatelizują i usprawiedliwiają, mącąc w głowach innych i skłaniając do podobnych postępków, by ich własne grzechy utonęły i skryły się w morzu zła, jakie wokół siebie wytworzyli ${ }^{23}$.

I tak fałszywi mędrcy swoje błędy cnotami zwą, czyniąc się dzięki nauce lepszymi, niż są w istocie. Pyszny więc zwie się wspaniałym, okrutny i tyran - sposobnym do rządu, pochlebca - wymownym i łagodnym, rozrzutny - szczodrym, skąpy - oszczędnym, niestateczny - biegłym, płochy - obrotnym, obmówca - prawdziwym, zazdrośnik - sprawiedliwym, chytry - umiejętnym, uparty - statecznym.

Przeciwnie zaś cnoty każą za niedoskonałości. Sprawiedliwy zostanie nazwany nieużytym i nieprzystępnym, mężny - grubianinem, szczery - nieostrożnym, dobry - miękkim i naiwnym, pobożny - hipokrytą. Wykorzystując nimb nauki i mieszając ze sobą dobro ze złem, cnotę z niecnotą, człowiek żadną miarą nie może dojść do prawdy ${ }^{24}$. Stawia więc tezę, iż nie przez naukę, a przez rozum przyrodzony wiedzie droga do cnoty. Rozum bowiem, byleby się chciał trzymać właściwej drogi, ma w sobie dość rozsądku, by człowieka zaprowadzić do chwalebnego i moralnie właściwego celu ${ }^{25}$. Lubomirski odwołuje się tutaj do Biblii, stwierdzając: „Wiedział tedy Bóg, że nauka i umiejętność miała zaszkodzić człowiekowi i dlatego ze wszystkich drzew rajskich używać pozwolił mu, ale z drzewa umiejętności cale zakazał". Wiedział On bowiem, że człowiek będzie się trzymał drogi cnoty dopóki zbytniej umiejętności i subtelności nauk nie skosztuje. Wąż, czyli diabeł, który się nazbyt przeuczył, chciał i człowieka zarazić swoją nauką. Do tej pory człowiek miał dość rozumu dla cnoty i rozsądnie poznawał, że mu się nie godzi łamać boskiego przykazania. Wąż jednak nauką nadrabiał. Wcielił się w rolę teologa, by od cnoty go odwieść, pytając o racje, dla których nie wolno im jeść z tego, a nie innego drzewa. Potem udawał moralistę, pokazując, że kto odróżnia dobro od zła, podobny jest samemu Bogu, by na koniec wejść w skórę polityka przenikającego Pańskie zamiary ${ }^{26}$.

${ }^{23}$ Ibidem.

${ }^{24}$ Ibidem, s. 31.

25 Taka charakterystyczna dla stoików pochwała prostego rozumu, przeciwstawianie „uczonej mądrości” i wiedzy czerpanej z książek rozsądkowi i mądrości pochodzącej z własnego doświadczenia, z przemyśleń i obserwacji przyrody, została prawdopodobnie przyswojona przez Lubomirskiego za pośrednictwem Montaigne’a, który według C. Hernasa był obok Seneki drugim nauczycielem stoicyzmu. Por. C. Hernas, op. cit., s. 488; R. Pollak, op. cit., s. LXIV.

${ }^{26}$ S.H. Lubomirski, Rozmowy..., s. 32. 
I tak po raz pierwszy człowiek poznał naukę! Ale czy przez to stał się mądry - pyta na koniec autor i odpowiada krótko - nie. „Mądrość, co się cnocie nie przyda, jest fałsz i maszkara głupstwu tylko potrzebna. Prostota rozumna i rozsądna to prawdziwa mądrość. Ani ten mądry, co siłę umie, ale ten, co umie umieć, cokolwiek umie, choć z przyrodzenia. Tak, że na mądrości używanie trzeba osobnej mądrości i miary" 27 .

Rozum i rozsądek przebijają z każdego tego słowa o mądrości - nie sposób zaprzeczyć. Nie każdy człowiek wykształcony jest mądry i nie każdy filozof musi kończyć szkoły. Są to śmiałe twierdzenia, biegnące jakby w poprzek życzeniom rodziców, którzy marzą o wykształconych dzieciach, jednak jakże charakterystyczne szczególnie w epoce, w której nauka nie stoi już tak wysoko wśród priorytetów rycerstwa. Wiek XVII wszakże to nie stulecie nauki, lecz wojny. Tylko teraz rodzi się pytanie, na ile $\mathrm{z}$ kolei on był szczery $\mathrm{w}$ głoszonych przez siebie poglądach? Polityk mówiący szczerze, co myśli o swych wyborcach, o planach i postrzeganym przez siebie stanie rzeczy, nie ma czego szukać w polityce. Prawda to tak stara, jak sama polityka. Taki magnat, jak Lubomirski i jemu podobni wielcy ówczesnego świata, też musiał raz na jakiś czas zbratać się z biedotą szlachecką, by zostać wybranym do sejmu czy trybunału. Z głębi duszy, jak większość współczesnych mu elit, prawdopodobnie pogardzał tą gołotą i zazwyczaj nie zniżał się do takiego poziomu, by ich dostrzegać, ale przed wyborami na krótką chwilę stawali się dla niego „panami braćmi”. I on sam, brzydzący się obłudą, musiał ich na sejmiku ugościć, wraz z nimi ucztować i pić, podlizując się im, by oddali na niego swoją kreskę. Widzimy zatem, iż ta wyszydzana polityka, która według Lubomirskiego nie sprzyja szczerości i poufałości, lecz skłania raczej do subtelności (czy - jak byśmy dziś powiedzieli - poprawności politycznej) i ostrożności w stosunkach z ludźmi i w wypowiedziach, również i jego zmuszała do postępowania wbrew sobie. Co nie wyklucza tego, że mógł być szczery w głoszonych przez siebie poglądach. Takie biczowanie (głównie zresztą elit) to nurt niezwykle popularny w ówczesnej publicystyce ${ }^{28}$. Ludzie, czytając o błędach, odnosili je raczej do innych, a jeśli do siebie, to również po to, by poczuć się lepiej, wiedząc, że nie oni jedni ten grzech popełniają.

Na zakończenie warto wspomnieć, iż Lubomirski w swoich poglądach na naukę nie był wcale odosobniony, ponieważ podobne wezwania pobrzmiewają od czasu do czasu nie tylko w literaturze tego okresu ${ }^{29}$, jak choćby postulaty odsu-

${ }^{27}$ Ibidem.

28 Wśród licznych tego typu dzieł zob np. P. Skarga, Kazania sejmowe, Wrocław 2010; M. Śmiglecki, Przestrogi do sumnienia należace. Od iednego miłośnika oyczyzny dla informaciey potrzebney P. P. Katholikom na elekcya zgromadzonym, y drugim ktorzy liberam vocem maia na Trybunałach, seymikach y seymach, [b.m.w.] 1632.

29 Por. K. Opaliński, Satyry, oprac. L. Eustachiewicz, Wrocław 1953, s. 108 i n. W satyrze VII, Na tych co się sobie mądremi i uczonemi zdadzą, siedemnastowieczny autor wyśmiewa współczesnych „mędrców”: „Tu u was, gdy kto sobie łaciną pomaże Gębę, zaraz uczony, zaraz 
nięcia jurystów od procesu tworzenia prawa ${ }^{30}$. Narzekania na prawników trwają do dziś, że tworzą prawo dla siebie po to, by potem korzystać z luk sobie tylko znanych albo gmatwać proste kwestie do takiego stopnia, że szary człowiek bez nich nie może już sobie poradzić.

\section{BIBLIOGRAFIA}

Arystoteles, O cnotach i wadach, [w:] Dzieła wszystkie, przeł. D. Gromska, L. Regner, W. Wróblewski, t. 5, Warszawa 1996.

Dąbkowska-Kujko J., Wprowadzenie do lektury, [w:] S.H. Lubomirski, Rozmowy Artaksesa $i$ Ewandra, w których polityczne, moralne i naturalne uwagi, zawarte wedle podanych okazyj, tak jako mówione właśnie były prawdziwie wyrażone sa spisane, Warszawa 2006.

Filon Aleksandryjski, Pisma, oprac. L. Joachimowicz, t. 1, Warszawa 1986.

Hernas C., Barok, Warszawa 1976.

Katechizm Kościoła Katolickiego, cz. 3, Pallotinum 1994.

Lubomirski S.H., Instrukcyja synom moim [do] cudzych krajów ode mnie wyprawionym, Teodorowi i Franciszkowi Lubomirskim, w Jazdowie, D. 29 Novembris A. 1699, [w:] Wybór pism, oprac. R. Pollak, Wrocław 1953.

Lubomirski S.H., Rozmowy Artaksesa i Ewandra, w których polityczne, moralne i naturalne uwagi, zawarte wedle podanych okazyj, tak jako mówione właśnie byly prawdziwie wyrażone sa spisane, Warszawa 2006.

Malarczyk J., Ulrich von Hutten o roli prawa i prawników w Niemczech, [w:] Dawne prawo i myśl prawnicza. Prace historyczno-prawne poświęcone pamięci Wojciecha Marii Bartla, red. J. Malec, W. Uruszczak, Kraków 1995.

Opaliński K., Satyry, oprac. L. Eustachiewicz, Wrocław 1953.

Orzechowski S., Dyalog albo Rozmowa około Exequcyey Polskiey Korony, [b.m.w.] 1564.

Pollak R., Wstęp, [w:] S.H. Lubomirski, Wybór pism, oprac. R. Pollak, Wrocław 1953.

Polski Słownik Biograficzny, red. E. Rostworowski, t. 18, Wrocław 1973.

Reale G., Historia filozofii starożytnej, przeł. E. Zieliński, t. 3, Lublin 1999.

Roszkowska W., Włoski rodowód komedii S.H. Lubomirskiego, Wrocław 1960.

Skarga P., Kazania sejmowe, Wrocław 2010.

Szczygieł W., Źródła „,Rozmów Artaksesa i Ewandra” S.H. Lubomirskiego, Kraków 1929.

Śmiglecki M., Przestrogi do sumnienia należace. Od iednego miłośnika oyczyzny dla informaciey potrzebney $P$. P. Katholikom na elekcya zgromadzonym, y drugim ktorzy liberam vocem maia na Trybunałach, seymikach y seymach, [b.m.w.] 1632.

Tatarkiewicz W., Trzy etyki: studium z Arystotelesa, [w:] Droga do filozofii, red. W. Tatarkiewicz, t. 1, Warszawa 1971.

człowiek godny [...] Cóżeś ty za filozof, że tam w szkołach trochę popiszesz termineczków, których nie rozumiesz [...]. W życiu nie w szkole ani w tych dysputacyjach. To jest prawdziwa mądrość: żyć według rozumu, a nie według mniemania”.

${ }^{30}$ Zob. S. Orzechowski, Dyalog albo Rozmowa około Exequcyey Polskiey Korony, [b.m.w.] 1564, k. E. Z kolei J. Malarczyk przedstawił popularne również w Polsce zdanie na temat prawników. Według niego są to „gwałciciele prawa i sprawiedliwości, nieznający w istocie, czym jest sprawiedliwość”. Zob. J. Malarczyk, Ulrich von Hutten o roli prawa i prawników w Niemczech, [w:] Dawne prawo i myśl prawnicza. Prace historyczno-prawne poświęcone pamięci Wojciecha Marii Bartla, red. J. Malec, W. Uruszczak, Kraków 1995, s. 152. 
Pobrane z czasopisma Studia Iuridica Lublinensia http://studiaiuridica.umcs.pl Data: 26/04/2023 12:50:18

\section{SUMMARY}

In the days of the fall of education, Stanisław H. Lubomirski proclaimed the superiority of the natural intellect and reason over academic knowledge. This well-known and respected magnate and philosopher, was called by his contemporaries "Polish Solomon". His views, in which one can see a clear trace of fascination with the Stoics, enjoyed great popularity until at least the middle of the eighteenth century.

Keywords: Polish education in the $17^{\text {th }}$ century; Stanisław H. Lubomirski; virtue; the Stoics 